\title{
Contextual Learning Concepts Drive Architectural Education to Partner with Industry
}

\section{Ms. Shahnaz J. Aly, Western Kentucky University}

Shahnaz Aly, LEED AP is an Assistant Professor in the Department of Architectural and Manufacturing Sciences at Western kentucky University. She has 3 years of experience in teaching and research, and 10 years professional experience in the architectural and construction industry. She is a registered architect in India. She earned her undergraduate degree in architecture from L.S. Raheja School of Architecture, Master of Architecture from Texas A \& M University along with a Certificate in Historic Preservation. Her interests include historic preservation, sustainability, and BIM.

\section{Ms. Laura Elizabeth Leach, Western Kentucky University}

Laura Leach, M. Arch. is a registered architect and assistant professor in the Department of Architectural and Manufacturing Sciences. She has ten years of experience in teaching and research including architectural drawing and documentation, studios, modeling, construction methods and materials, and management. She also has three years of professional experience in architectural practice and the construction industry. 


\section{Contextual Learning Concepts Drive Architectural Education to Partner with Industry}

\section{Introduction}

The field of architecture is people oriented, which cannot be practiced in isolation. From concept to completion the focus is always on the end user. According to Gutman, buildings are objects of use apart from being objects of pleasure ${ }^{[1]}$. Architecture is so essentially a social art that no architect can talk about his (or her) medium or about his (or her) schemes without reference to how they will be used by people ${ }^{[1]}$. Once the idea for a facility has been conceptualized, the designer begins to conceptualize solutions for that particular structure, while taking into consideration the people who are to use and visit the facility, and keeping in mind functionality, occupant safety, comfort, and aesthetics. The construction team is responsible for executing these designs and using their expertise to make sure that materials used and procedures followed will result in a safe and healthy environment for the occupants.

Design professionals also have a responsibility to the environment and to future generations. Architects have the responsibility of minimizing pollution and ecological damage, adverse biological effects on occupants, being sensitive to and in harmony with surroundings affecting

the human individualities who will come in contact with the building ${ }^{[2]}$. Building-related construction and demolition (C\&D) debris totals approximately 160 million tons per year, accounting for nearly 26 percent of total non-industrial waste generation in the United States. By combining C\&D with municipal solid waste (MSW), two-thirds of all non-industrial solid waste generation in the US is due to building construction, renovation, use and demolition ${ }^{[3]}$. The role of the designer is not simply new construction but also adapting and reusing existing structures to minimize the impact on landfills.

In the Department of Architectural and Manufacturing Sciences (AMS) at Western Kentucky University (WKU) the Architectural Science program is continuously evolving and finding innovative ways to help students gain an understanding of the role and responsibilities of architects. Students are provided a solid conceptual and theoretical foundation through numerous courses. The faculty felt the need for more contextual based learning to complement their coursework. The hands on approach would introduce students to the real world, provide an opportunity to students to interact with a real client and solve real problems.

\section{Literature Review}

According to Baker, Hope and Karandjeff there is a growing shift from the traditional classroom where the active role rested with the instructor and the students held the passive role. This shift is termed as "constructivism" where the instructor's primary responsibility is to create student engagement in the learning environment. Contextual Teaching and Learning (CTL) is seen as a promising strategy that can actively engage students and promote improved learning and motivation for students ${ }^{[4]}$. The central message of CTL is "learning by doing causes us to make connections that yield meaning, and when we see meaning, we acquire and retain knowledge and skills." "5] Johnson believes that the CTL approach is a "holistic system" and consists of various 
components which include: (1) making meaningful connections, (2) doing significant work, (3) collaborating and self-regulated learning, (4) critical and creative thinking, (5) nurturing the individual, (6) reaching high standards, and (7) using authentic assessment. When these parts are applied as a whole, they help students make connections and retain information ${ }^{[5]}$. In describing the importance of contextual learning for engineers Palmer, Terenzini, Harper and Merson discuss the following areas where Massachusetts Institute of Technology (MIT) found value in providing context, (1) to help learn the subject matter, (2) to motivate and engage students, (3) to develop professional skills, and (4) to find technical solutions ${ }^{[6]}$.

Collaboration is seen as an essential component of the CTL system. Such collaborations can be fostered between the school and businesses, non-profit organizations and the local community. When students are exposed to these partnerships and work with these groups it helps them to learn to respect others, listen to opinions and build consensus ${ }^{[5]}$. While exploring the notion of contextual learning, the faculty engaged the local community to build and forge partnerships. Community involvement is seen as one way to help schools produce a more capable work force; by equipping schools to provide students with more relevant, challenging learning opportunities in nurturing environments ${ }^{[7]}$. According to Sanders, partner selection is important and schools should identify community partners and develop partnerships that will help them to achieve goals that support students' learning. Sanders also suggests that service learning partnerships are a popular form of community involvement in schools, helping achieve educational objectives which focus on community and civic partnership ${ }^{[7]}$.To build such a partnership, the AMS faculty approached the City of Bowling Green to explore potential opportunities for involving students in projects that would be mutually beneficial.

According to Schuman the history of service-learning in schools of architecture and planning can be found in the late 1960s where schools emphasized engaging students in the social issues and supplementing classroom learning with community contact. Due to different circumstances through the years' service-learning has been more broadly accepted in planning programs than in architecture departments. A resurgence of interest in social engagement in professional practice of architecture and schools can be seen in the late 1990s early 2000. ${ }^{[8]}$ According to Rios, "of the 123 architecture schools that offer a professional degree in North America, over $30 \%$ run university-based community design and research centers. ${ }^{[9]}$

In reviewing architecture programs at universities such as Auburn University ${ }^{[10]}$, University of Arizona ${ }^{[11]}$, and University of Arkansas ${ }^{[12]}$ we have found that faculty in these programs have partnered with other disciplines such as engineering and the local community (urban \& rural) to work on design-build projects. At the Rural Studio that originated at Auburn University under faculty members Samuel Mockbee and D.K. Ruth, architecture students from the second year to fifth year had the opportunity to "live, learn and give back" to Alabama's Black Belt, one of the country's most impoverished regions through design-build residential projects. ${ }^{[10]}$ The College of Architecture, Design and Construction at Auburn University, also created the Urban Studio to facilitate the working of undergraduate architecture students with faculty on design charrettes and develop a plan for the community ${ }^{[10]}$. According to Gaber and Bennett, "students felt empowered by their close interaction with an appreciative client." [10]

In planning schools through the United States such as California State Polytechnic University, Pomona, a HUD Community Outreach Partnership Center (COPC) grant was secured through 
which students and faculty worked alongside the community and engaged communities in planning processes and decision making ${ }^{[13]}$. University of California at Los Angeles (UCLA) established the Community Scholars Program (CSP) as a prototype for service-learning. Through the CSP initiative joint architecture-urban planning studios have "worked with two L.A. public housing developments". [14]

The Architectural Science faculty chose a senior level architectural documentation course for implementation of the partnership with the City of Bowling Green. This course has an emphasis on investigation and renovation of existing structures. The City of Bowling Green has a number of facilities that are either lying vacant or underutilized. In support of the partnership, the City selects facilities that the students could use to study for adaptive reuse. This project provided the students a unique perspective into the premise of exploring existing structures for reuse. This requirement forced students to be aware of the people who had used the structures previously especially in historic buildings and the people who would be using the structure in the future. The first time the course was offered was in Fall 2009. During that semester, the class project was a redesign of the Old Jail in Downtown Bowling Green that was being used by Warren County Emergency Management. The client was looking for ideas on expansion of the facility and the students provided them with design concepts. In the spring of 2010, the students worked on a historic automotive building which was occupied by the Downtown Redevelopment Authority (DRA). The client wanted ideas on how the building could be better utilized to draw students from Western Kentucky University to the downtown core. In the same semester the students also worked on a historic hardware building. The most recent project example is the City Hall Annex building project which will be discussed in the case study below.

\section{Case Study}

The city facilities are primarily housed in the City Hall building, City Hall Annex and the Public Works Department building all located in the downtown core. The city needed to relocate some of the departments from City Hall Annex to create free space for other units of the city, which were being housed in rented spaces. The City Hall Annex houses Neighborhood \& Community Services, Finance, and Information Technology. Of these, Neighborhood \& Community Services were to be relocated and the Law Department and Records were to be brought into the facility. This case study highlights the methodology and discusses the outcomes and benefits of the partnership.

The Architectural Documentation III class meets twice a week for 4 hours each week. A detailed schedule of the class was created so that the students create a timeline for each activity that was to be undertaken. During the first week of class the faculty met with the City Manager to discuss potential projects for the semester and City Hall Annex Building was identified as the project for students to work on. The students were introduced to the project and a meeting was arranged by the faculty with the City Manager of Bowling Green. The City Manager gave the students a tour of the facility to be renovated and a summary of all the requirements for the facility.

Since there were no detailed drawings of the facility, the first task the students were assigned was the documentation of the structure, including field measuring and photographic documentation. One of the challenges of field measuring was that the facility was occupied and the students had to work around the schedule of the employees to minimize work disruption. The 
faculty mentored the students through the field measurement process and directed them on techniques for documenting the structure. For measuring, students were divided into three groups: two groups were tasked with measuring the exterior of the structure, while the third group measured the interior of the structure as shown below in Figure 1. The faculty was present during every class meeting that the students were on-site to guide and direct them.

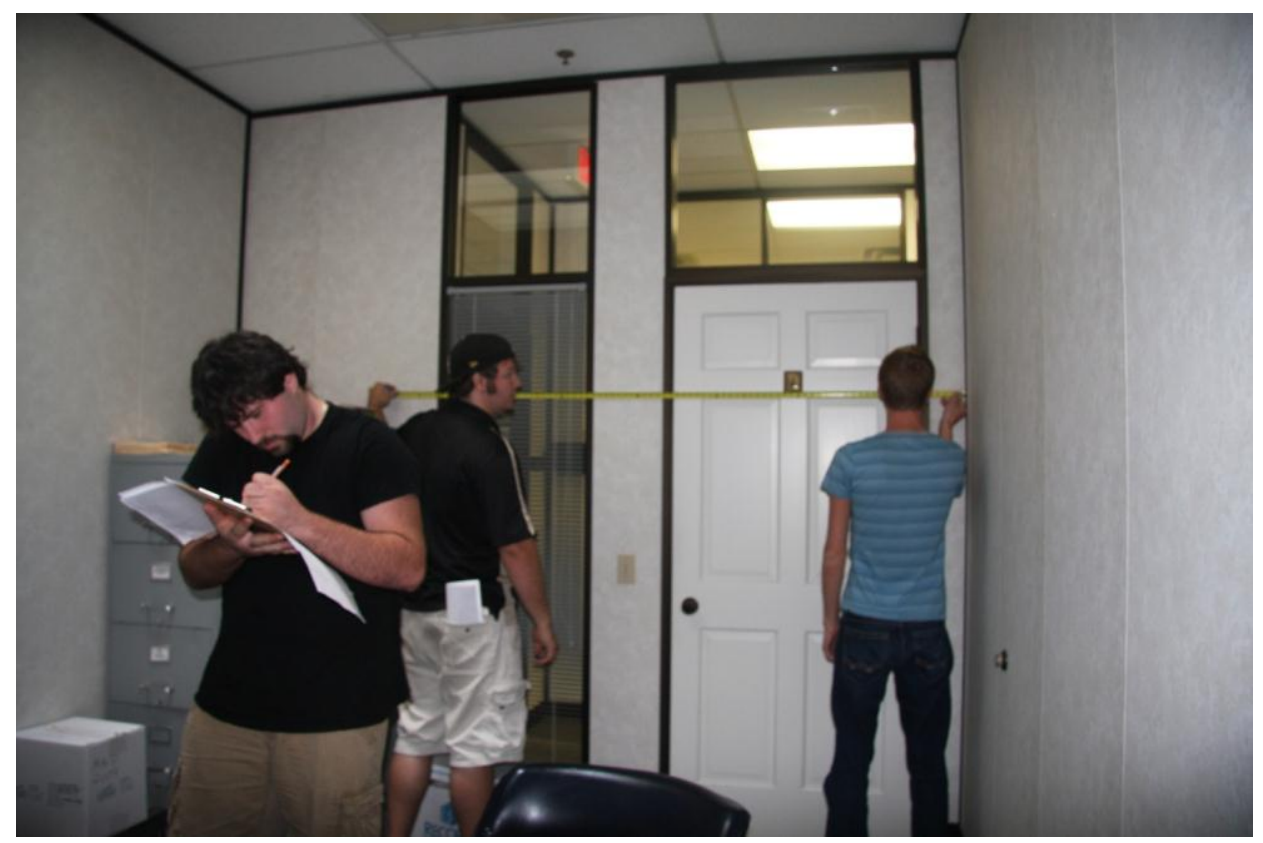

Figure 1: Field measurements of City Hall Annex

Additionally, two students were assigned with interior and exterior photo documentation. The purpose of the photographs was to identify problematic areas so that the client would be able to address these issues. After each measuring session the students went back to the classroom and drafted the measurements using AutoCAD to check the accuracy of their field measurements before they revisited the site.

The onsite measurements took approximately six weeks to complete. During this time, the faculty facilitated student directed meetings with the various department supervisors in the City of Bowling Green. One of the course requirements assigned early in the course was the development of a questionnaire for these meetings. As a result of the meetings, the students learned the current status, requirements, and future needs of each department that was to be located in the facility. The meetings were approximately one hour in duration and the students had to submit a summary of each meeting, which formed a part of the students' work that they were being graded on. After meeting with all the departments, the results were compiled into a master document which became the program for the project. The compilation of the document was done by one student under the supervision of the faculty. This master document was sent to each department supervisor as well as the City Manager for approval. This document became the program for the renovation of the facility.

Students also created the as-built drawings for the structure; each student took a key role in developing the plans, elevations, sections and photo documentation of interior and exterior 
problem areas. The faculty reviewed and redlined every drawing prepared and a grade was assigned based on the quality and accuracy of work produced. Since the City Hall Annex was situated in the historic downtown core of Bowling Green, one of the students was assigned the task of preparing a historic report detailing original construction dates, uses, and subsequent additions to the building. From these initial six weeks of work, a set of as-built drawings were generated, two examples are seen in figures $2 \& 3$.

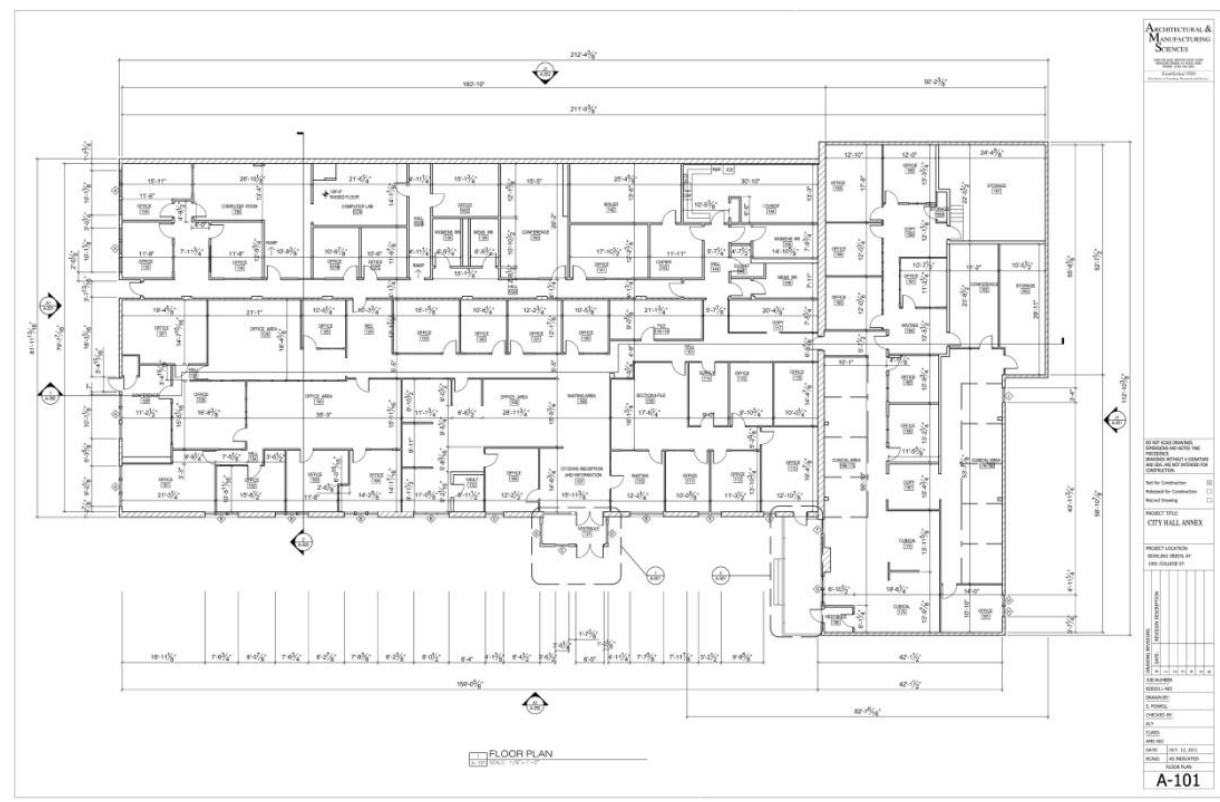

Figure 2: As-built drawing for City Hall Annex

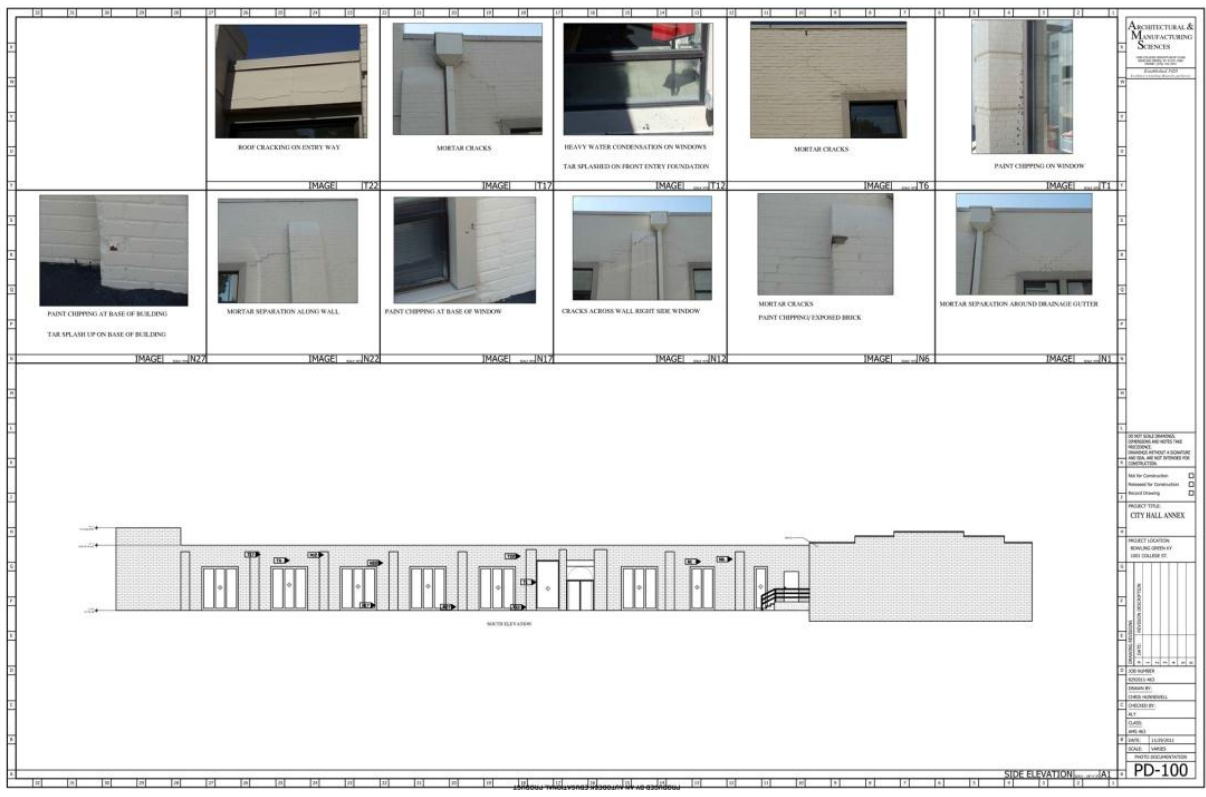

Figure 3: Photo documentation of City Hall Annex 
The next six weeks were dedicated to re-design of the structure based on the program developed by the students. Based on performance of students in the first stage of the course, the faculty assigned students to work in teams. Three types of teams were created; Economy Design Team, Moderate Design Team and Aggressive Design Team. The Economy Design Team was assigned with the task of redesign with minimum demolition while satisfying the client's needs. They worked to keep most of the existing walls and spaces while relocating some functions and providing the required space for the new functions introduced to the structure as seen in figure 4 .

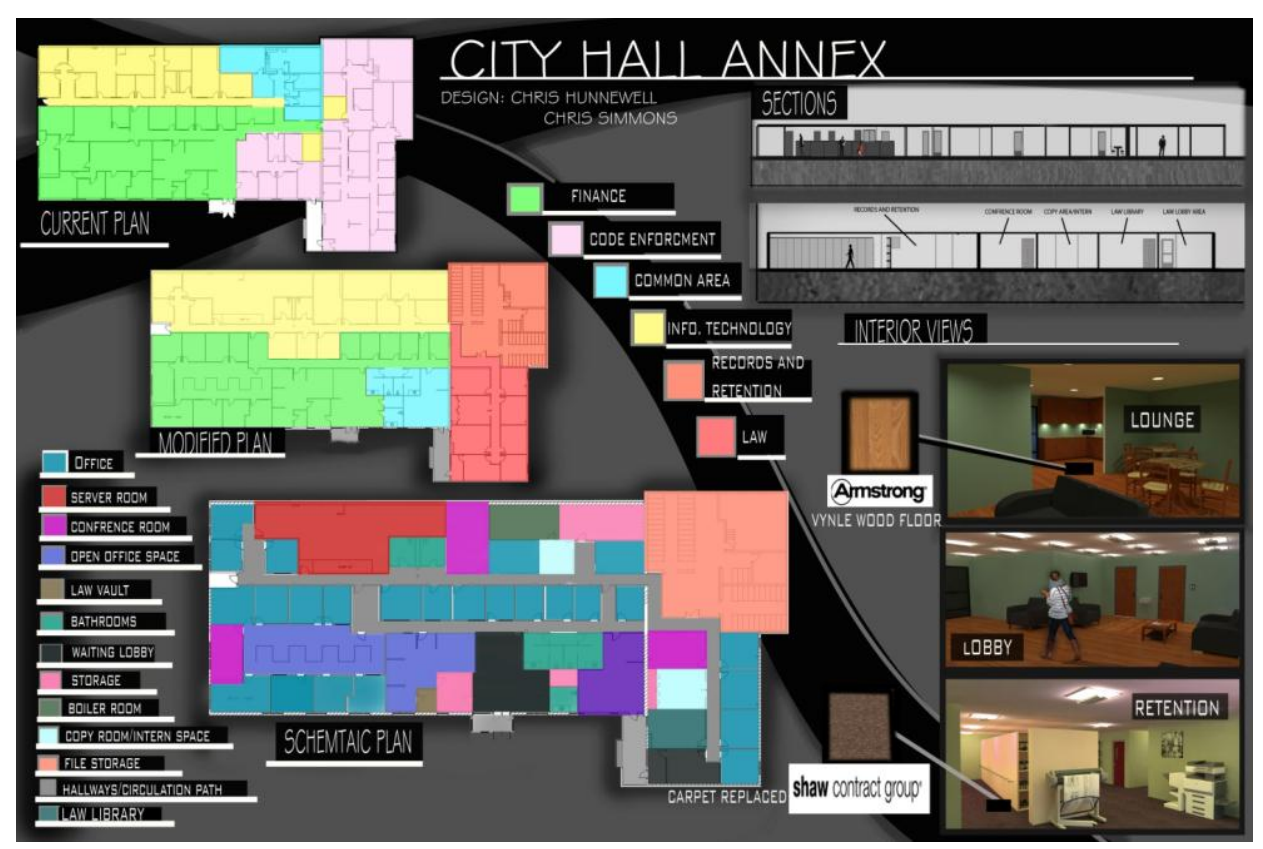

Figure 4: Economy Design Team Proposal for City Hall Annex

The Moderate Design Team had a mandate for substantial interior demolition but minimum exterior demolition. These teams made interior modifications such that the units had a better spatial organization and also proposed certain changes to the exterior of the structure as seen in figure 5 . 


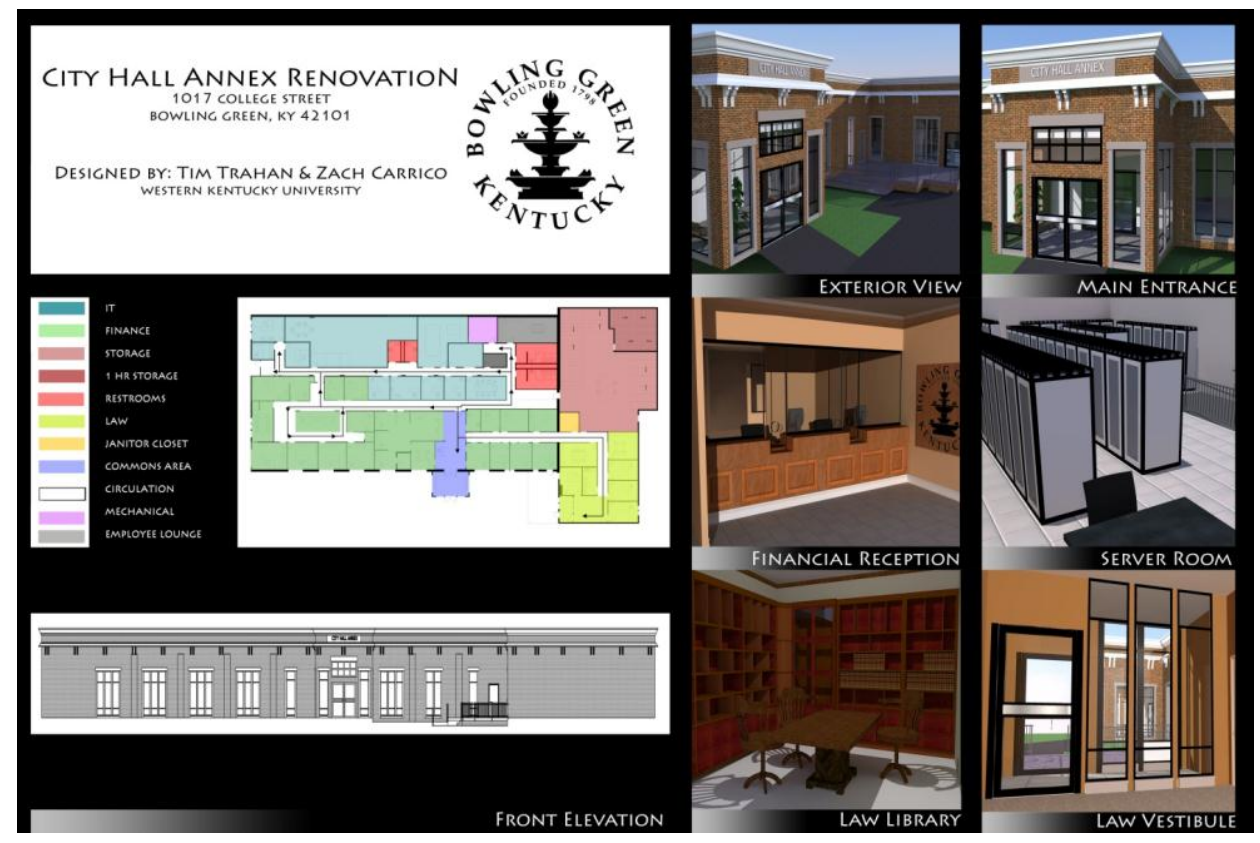

Figure 5: Moderate Design Team proposal for City Hall Annex

The Aggressive Design Team was mandated with the task of achieving the client's needs with substantial interior demolition as well as possible additions to the exterior. The results of the design of the Aggressive Design Team are shown in Figure 6 below.

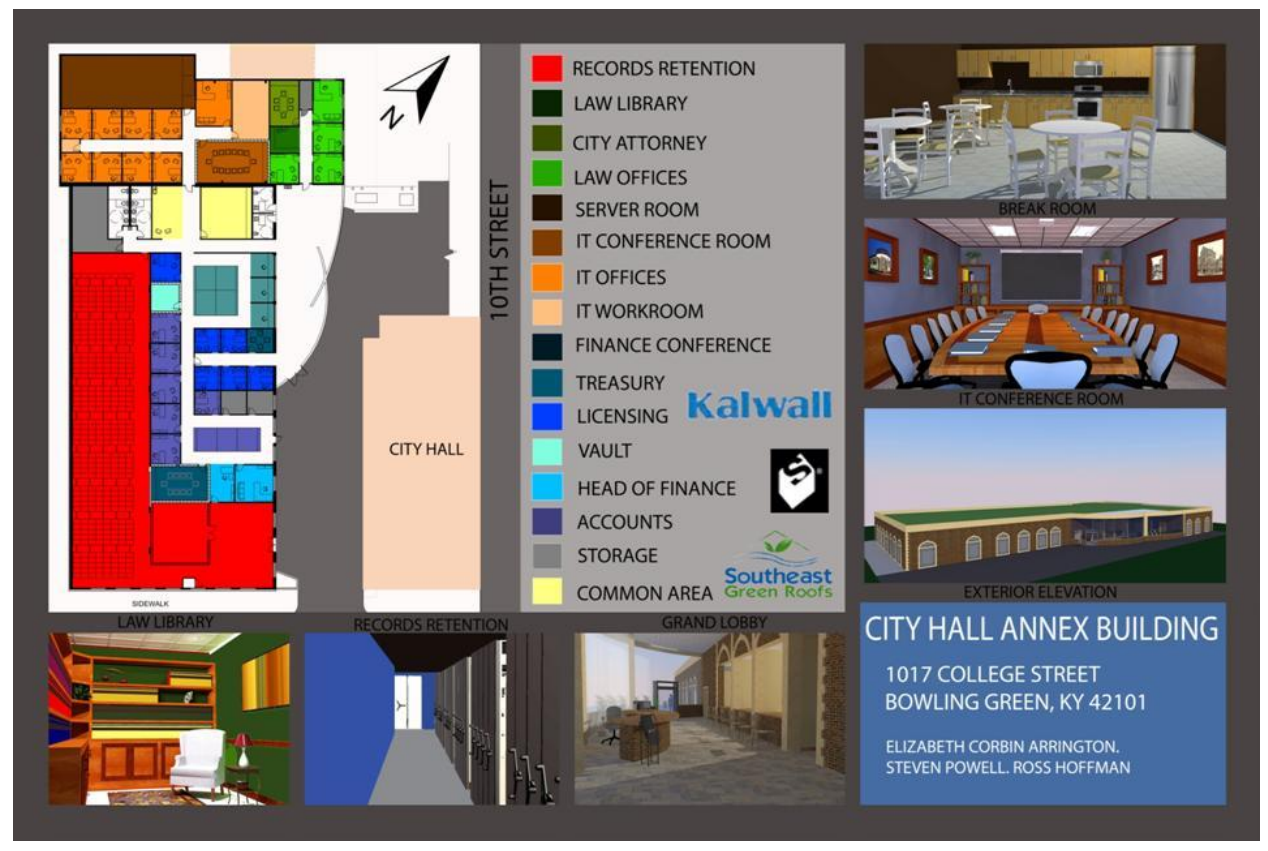

Figure 6: Aggressive Design Team proposal for City Hall Annex

From this point in the semester, the students' work was conducted in the classroom. The students had to apply their knowledge gained from other classes, especially in terms of applicable codes, structures, and design studios. The faculty critiqued student designs and provided them with 
feedback from the point of view of design, codes and client program. After the first week of schematic design, the students presented their initial ideas to the other teams. Week ten was the conclusion of schematic design and groups now had the task of generating construction drawings, presentation drawings, and demolition drawings for the client. The students had knowledge of construction drawings from prior documentation classes and presentation knowledge from the various design studios. Preparing demolition drawings was new to the students and a lecture was conducted to demonstrate to the students how such drawings would be created. At this stage the faculty also reviewed, redlined and graded the construction and demolition drawings. One of the criteria for the projects was the use of sustainable products. The students researched aspects of sustainability for flooring, lighting, and furniture among others.

The last part of the fifteen week course was the presentation of schemes to the City. The city officials meet once a month and they provided the students an opportunity to present their design solutions at one of these meetings. For these presentations, students prepared boards and detailed Power Point presentations highlighting various aspects of their design. The students also created three-dimensional drawings to make their concepts as realistic as possible. City officials, other faculty from the AMS department, and families of the students attended the presentations as shown in figure 7. Each team was given ten minutes of presentation time followed by questions from the audience. The final week involved collating all the information together and printing the set of construction and demolition drawings to provide to the city. The work was well received by the City. Feedback from officials included comments on the cost effectiveness of ideas, fulfilling needs and requirements and a general consensus that the quality of work exceeded expectations.

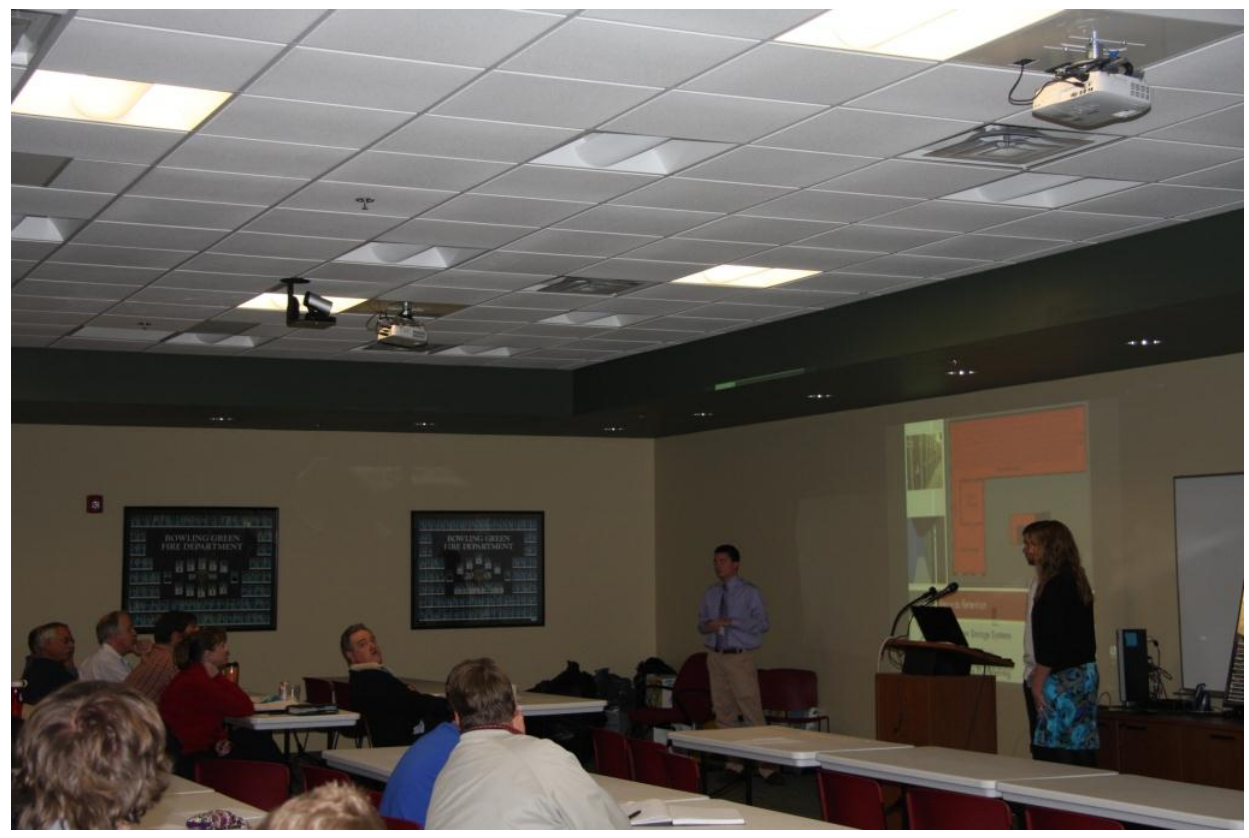

Figure 7: Student presentation to city officials 


\section{Evaluation}

There were three forms of evaluation for the project: the faculty evaluation of the individual students work during the course of the semester, the community-partner evaluated the students work during the final presentations that the students made at the conclusion of the project and the students also self-evaluated their work through reflections that they completed in the final week of the class.

At the start of the semester the faculty created grading criteria for the semester. The grading criteria were based on the major components of work that the students were to perform during the project. The criteria are listed in the table 1.

\begin{tabular}{|l|l|l|}
\hline Grading Criteria & & \\
\hline 1. & Field Measurements \& Notes & $25 \%$ \\
\hline 2. & As-Built Drawings & $15 \%$ \\
\hline 3. & Schematic Design \& Research (community partner feedback) & $15 \%$ \\
\hline 4. & Construction Documents & $15 \%$ \\
\hline 5. & Demolition Drawings & $15 \%$ \\
\hline 6. & Presentation (community partner feedback) & $10 \%$ \\
\hline 7. & Final Exam (student reflections) & $05 \%$ \\
\hline
\end{tabular}

Table 1: Grading Criteria

The first two parts of the grading criteria were based on the field work and resulting drawings that took place during the first six weeks of the semester. Evaluation took into account student participation, quality of notes and observations that were submitted on a weekly basis to the faculty, and the resulting accuracy and quality of the as-built drawings. During the next six weeks when the students were working on the schematic design, construction and demolition drawings they were evaluated on group performance and also on individual contributions towards design, sustainability and creation of the required drawings. The feedback received from the community partner about the design quality was also a factor in determining students' grade. Grades for presentation were based on the quality of the presentation board, power points created and community partner feedback.

For the schematic design stage of the project, the students worked in groups. There were five groups that presented their work to city officials. The community partner rated the student groups on their professionalism, communication skills, initiative, design ideas and overall quality of the project. They were evaluated on a scale of excellent, good, average, poor and very poor. Of the feedback received most of them received a good to excellent rating for the above five factors. Only one group received a poor rating for communication skills. The officials were very 
satisfied with the creative ideas that were presented about how the facility could be reused and saw that as a major strength of all the teams. The community-partner was of the opinion that the projects, at the minimum, met expectations, and of the five groups who presented, three groups exceeded their expectations.

After the completion of the presentations and receiving feedback from the city officials the students reflected on the project and the impact that their work had on the community and what they had learned from the project. There were eleven students in the class and they each answered a set of questions ranging from their learning experiences, frustrations faced during the project, experiences of working in a group, application of knowledge from previous classes, and how they were able to contribute to the community. Overall the students reacted very positively to the experience. They were excited to work with a real client and felt that it would be beneficial to them when they went out into the real world. Most of the students agreed with the fact that they learned a lot from this experience not just in terms of technical skills but also communication and interaction with clients and time management. They also felt that they were able to apply their knowledge from previous courses towards the success of the project. Some students expressed frustrations of working in groups and that there was lack of commitment from their partner during the project. Students also expressed frustration about the first part of the project when they were measuring the existing building claiming that not all their classmates were committed to the project and that work slowed down due to delays on the part of some students.

\section{Outcomes \& Conclusion}

Through this partnership with the City of Bowling Green the faculty felt that there has been increased student learning and benefit to the community.

\section{Student Learning}

Designing for adaptive reuse is a unique challenge which requires an intimate understanding of what future occupants need from the structure, and the enormous financial and environmental savings and benefits that result from reuse rather than potential demolition and construction of new facilities. After the course, students are able to understand older construction typology, identify structural and code problems in the spaces, appreciate historic aspects of these places, and understand the environmental benefits of adaptively reusing these facilities. Since these facilities were built at a different time and for different uses than what they are being adapted for, the students have to familiarize themselves with the new users that are to occupy the facilities. Students study spatial requirements and code requirements for occupant safety, while focusing on the aesthetics of the space. The students spend time measuring and documenting the facility and prepare as-built drawings, which is a new learning experience. Also, students learn how to interact and work with a client, which is an important aspect of the profession. The students conduct numerous meetings with the client to understand wants and needs for the facilities. The students also learn how to create demolition drawings as part of the package of drawings created for the City.

Ambrose suggests if students realize the intrinsic value of their work as well as the extrinsic rewards that can be gained from it; they will be motivated ${ }^{[15]}$. Through the partnership projects, 
the students are taken out of the traditional classroom setting and are exposed to real world situations. While working on design proposals, they use the knowledge acquired in other classes related to design, codes, structures and building systems. To prepare construction drawings the students use their skills from the mid-level documentation class where they learn how to put together a set of construction drawings. For their presentations, the students use threedimensional software that they have learned previously. They see a clear correlation between theory and its application. They conduct research on types of presentation boards, which helps them improve presentation styles and techniques that are important when they are out in the field seeking employment or presenting a project to a client. They use their skills from presentations they have done in the design studios to make an effective and convincing presentation of their design solutions.

\section{Community Benefits}

Since 2009 when the course was first offered, we have worked with various city agencies on multiple facilities that have been lying vacant or underutilized to give them design ideas for reuse. Their facilities have been documented and they are made aware of the problems that exist from structural, occupant safety, and code related points of view. They can choose to move forward and rectify any immediate problems which could threaten the integrity of the building and safety of its occupants. The design solutions provided by the students have been highly educational for the city officials. The City was informed of the possibility the structure affords and how this redesign can be a successful project. The City was also provided drawings for future cost estimates. They were able to see student potential and fresh ideas that the students generated for these facilities. The work done by the students proved to be of significant value to the City.

In spring 2011, the Architectural Science faculty made a decision to approach the design schemes based on the three team model (Economy, Moderate and Aggressive). According to the faculty the approach has had a two-fold benefit; (1) the students had to come up with innovative designs within the physical constraints of the structure and the amount of demolition that their team could perform, (2) for the City, this approach gave them options to evaluate costs and to be able to integrate designs from each option to find the optimum solution that would satisfy their wants and needs. Since this approach has been adopted, the City has done cost estimates using interior options of one solution and exterior options from another thus being able to find a happy medium between cost and design. While the students in the Architectural Science program had limited exposure to construction costs, the design approach based on the amount of demolition made them aware of cost ramifications from the point of view of labor, transportation of demolished material to landfills, cost that could be incurred on new construction, materials, labor and transportation. The faculty emphasis on use of sustainable materials for any new construction highlighted the responsibility of the profession to the environment. Using the ideas from the student designs, the City Manager of Bowling Green recently received approval from the City Commissioners to move ahead with the project and bids were called for professional services for the building discussed in the case study. 


\section{References}

[1] Gutman, R. (2010). The Questions Architects Ask. Architecture From the Outside In. Princeton Architectural Press, New York.

[2] Day, C. (2004). Places of the Soul Architecture and Environmental Design as a Healing Art. Burlington, MA: Architectural Press.

[3] U.S, EPA. (2009, April 22). Buildings and Their Impact on the Environment: A Statistical Summary. Retrieved from Green Building: www.epa.gov/greenbuilding

[4] Baker, E.D., Hope L., Karandjeff, K. (2009). Contextualized Teaching \& Learning: A Faculty Primer. Funded by The Chancellor's Office Of The California Community Colleges.

[5] Johnson, E. B. (2002). Contextual Teaching and Learning. Thousand Oakes, CA: Corwin Press, Inc.

[6] Palmer B., Terenzini P., Harper B., Merson D. (2011). Design In Context: Where Do The Engineers Of 2020 Learn This Skill.Conference Proceedings from American Society for Engineering Education.

[7] Sanders, M. G. (2006). Building School-Community Partnerships: Collaboration for Student Success. Thousand Oaks: Corwin Press.

[8] Schuman, A. W. (2006). Introduction: The Pedagogy of Engagement. In Hardin, M.C, Eribes, C., Poster, C. (Volume Eds.), Zeisel, W.(Series Ed.). From the Studio to the Streets: Service-Learning in Planning and Archtiecture. Sterling, VA: Stylus Publishing.

[9] Rios, M. (2006). Where Do We Go from Here? An Evaluative Framework for Community-Based Design. In Hardin, M.C, Eribes, C., Poster, C. (Volume Eds.), Zeisel, W.(Series Ed.). From the Studio to the Streets: Service-Learning in Planning and Archtiecture. Sterling, VA: Stylus Publishing.

[10] Gaber, S., Bennett, D. (2006). Institutional Support for Community-Based Architecture and Planning Outreach Scholarship at Auburn University. In Hardin, M.C, Eribes, C., Poster, C. (Volume Eds.), Zeisel, W.(Series Ed.). From the Studio to the Streets: Service-Learning in Planning and Archtiecture. Sterling, VA: Stylus Publishing.

[11] Hardin, M.C. (2006). Research as Ethical Practice: When Academic Goals Align with Community Needs. In Hardin, M.C, Eribes, C., Poster, C. (Volume Eds.), Zeisel, W.(Series Ed.). From the Studio to the Streets: Service-Learning in Planning and Archtiecture. Sterling, VA: Stylus Publishing.

[12] Wing, S. (2006). Sore Shoulders, Bruised Ethics: The Unintended Lessons of Design Build. In Hardin, M.C, Eribes, C., Poster, C. (Volume Eds.), Zeisel, W.(Series Ed.). From the Studio to the Streets: ServiceLearning in Planning and Archtiecture. Sterling, VA: Stylus Publishing.

[13] Lund, H.M., Urey, G. (2006). Achieving Large-Scale Community Development Projects in a Teaching University. In Hardin, M.C, Eribes, C., Poster, C. (Volume Eds.), Zeisel, W.(Series Ed.). From the Studio to the Streets: Service-Learning in Planning and Archtiecture. Sterling, VA: Stylus Publishing.

[14] Leavitt, J., Heffernan, K. (2006). Multiplying knowledge: Service-Learning x Activism = Community Scholars. In Hardin, M.C, Eribes, C., Poster, C. (Volume Eds.), Zeisel, W.(Series Ed.). From the Studio to the Streets: Service-Learning in Planning and Archtiecture. Sterling, VA: Stylus Publishing.

[15] Ambrose, S. A., Bridges, M. W., DiPietro, M., Lovett, M. C., \& Norman, M. K. (2010). How Learning Works: Seven Research-Based Principles for Smart Teaching. San Francisco: Jossey-Bass. 